\title{
Growth and yield response of two hybrid rice cultivars to ATONIK plant growth regulator in a Tropical environment
}

\author{
Ben K. Banful ${ }^{1 *}$, Daniel Attivor ${ }^{2}$ \\ ${ }^{1}$ Kwame Nkrumah University of Science and Technology, University Post Office, Private mailbag, \\ Kumasi, Ghana \\ ${ }^{2}$ Calli Ghana Company Limited, P.O.Box TT 503 Tema, Ghana
}

Received: 6 October 2016

Accepted: 28 February 2017

Published online: 15 March 2017

\begin{abstract}
A study was conducted at the Department of Horticulture, KNUST, Kumasi from June to November, 2015 with the objectives to (i) determine the rate of ATONIK plant growth regulator (PGR) suitable for high yield of two varieties of hybrid rice (ii) determine the combined effects of PGR rates and varieties on the growth and yield performance of hybrid rice. A 2 × 5 factorial arrangement in randomized complete block design with three replications was used. The factors were varieties at two levels: Agra Rice and Jasmine 85 and PGR at five levels: ATONIK at $450 \mathrm{ml} / \mathrm{ha}$, ATONIK at $500 \mathrm{ml} / \mathrm{ha}$, ATONIK at 550 $\mathrm{ml} / \mathrm{ha}$, ATONIK at $0 \mathrm{ml} / \mathrm{ha}$ and $\mathrm{GA}_{3}$ at $60 \mathrm{ml} / \mathrm{ha}$. Comparing the ATONIK rates with the $\mathrm{GA}_{3}$, ATONIK at $450 \mathrm{ml} / \mathrm{ha}$ resulted in a $14.3 \%$ increase in the number of rice panicles. Application of ATONIK at $450 \mathrm{ml} / \mathrm{ha}, 500 \mathrm{ml} / \mathrm{ha}$ and $550 \mathrm{ml} / \mathrm{ha}$ resulted in $14.4 \%, 10.7 \%$ and $4.4 \%$ higher percentage of productive tillers, respectively, than that produced by $\mathrm{GA}_{3}$ at $60 \mathrm{ml} / \mathrm{ha}$. ATONIK at $450 \mathrm{ml} / \mathrm{ha}$ application led to a $17.8 \%$ increase in grain yield. For the harvest index, application of ATONIK at $450 \mathrm{ml} / \mathrm{ha}$ resulted in the highest harvest index of $45 \%$, significantly greater than the other PGR treatments. In conclusion, the study clearly demonstrated that ATONIK PGR was superior to $\mathrm{GA}_{3}$ in the vegetative and productive performance of rice. The most suitable rate of ATONIK for increased rice productivity was $450 \mathrm{ml} / \mathrm{ha}$.
\end{abstract}

Keywords: plant growth regulator, rice, vegetative growth, yield

\section{Introduction}

Rice (Oryza sativa L.) is one of the world's main staple crops, with nearly 2.5 billion people depending on it. Rice is cultivated in many developing countries and is the primary source of income and employment for more than 100 million households in Africa and Asia. In Africa, rice is the fastest growing food source (Nwanze et al. 2006). It provides more than one third of the cereal calorific intake in West Africa.

In Ghana, rice is the second most important cereal after maize and it is fast becoming a cash crop for many farmers (MiDA 2010; Osei-Asare 2010; Bam et al. 1998). Annual per capita consumption

\footnotetext{
* Corresponding author: Ben K. Banful

e-mail: bproofa@gmail.com
} 
of rice is growing rapidly from 17.5 kilogram in 1999-2001 to 24 kilogram in 2010-2011 (MOFA 2011a), and its demand is projected to be at a rate of 11.8 percent in the medium term (MiDA 2010). Nonetheless, the totality of rice grain obtained from the local rice fields only meet about $40 \%$ of the country's rice demand, making Ghana a net importer of the commodity (FAO 2008). These low rice yields have been attributed in part to inadequate nutrition for the growing plant particularly at the reproductive stage where the nutritional demand of the plant tremendously increases (Al-Hassan 2008; Bam et al. 1998; MOFA 1999; MOFA 2000). This situation of consistent low yields can however be overcome through the exploitation of hybrid varieties in the farmers cropping systems. In recent times, farmers are adopting the use of hybrid rice varieties because of their perceived potential to produce high yields. However, these high yields are achieved through an expression of the hybrid vigour of the varieties which are being effectively exploited and sustained through the use plant growth regulators (PGR). Plant growth regulators are organic compounds, other than nutrients, that modify plant physiological processes and are active at very low concentrations in plants (Gianfagna 1987). They act inside plant cells and play important roles in plant growth, yield and quality formation of crops (Ekamber and Kumar 2007). Furthermore, PGRs regulate the amount, type and direction of plant growth with remarkable accomplishments of improved plant development and enhanced yield in several crops been documented (Shah et al. 2006; Emongor 2007). For instance, Auxin, a PGR, regulators cell elongation, tissue swelling, cell division and formation of adventitious roots, among others (Woodward and Bartel 2005; Abel and Theologis 2010). Similarly, Gibberellic acid, another PGR, participates in the regulation of many growth and development processes in various plants, including rice (Richards et al. 2001; Sakamoto et al. 2004; Sun 2004). Rajendra and Jones Jonathan (2009) also reported that application of plant growth regulators could improve the photosynthetic capacity, delay the leaf senescence and promote the rate of rice seed-setting. Presently, in Europe, Asia, the Middle East and the Americas, a plant growth regulator that has been commercialized for the treatment various annual and perennial crops is ATONIK. Studies on ATONIK show positive effects on (i) vegetative growth of seedlings, shoots, roots and branches (ii) reproductive growth in number of flowers and number of fruits and (iii) biomass accumulation (both fresh weight and dry matter) and yield (Arysta Life Science 2014). Presently it is used in the cultivation of oilseed rape, potato, sugar beet, sunflower, maize, soybean, fruit trees, berries, olives, grapes, citrus, cucurbits, solanaceous, leafy and root vegetables. However, for rice, there is a dearth of information on the use of ATONIK.

The objectives of this study therefore were to (i) determine the rate of ATONIK PGR suitable for high yield of two varieties of hybrid rice (ii) determine the effects of ATONIK PGR and GA3 on the growth performance of two varieties of hybrid rice and (iii) determine the combined effects of PGR rates and varieties on the growth and yield performance of hybrid rice.

\section{Methodology}

\subsection{Experimental location}

The study was conducted at the Department of Horticulture, KNUST, Kumasi from June to November, 2015. The site is in the semi-deciduous forest zone with an elevation of $186 \mathrm{~m}$ above sea level (ASL) and a bimodal rainfall distribution. The major rainy season is from late March to mid-July. There is a short dry spell from mid-July to mid-September followed by the minor rainy season from mid-September to mid-November. The mean annual rainfall is $1500 \mathrm{~mm}$. The mean minimum and maximum temperatures are $21{ }^{\circ} \mathrm{C}$ and $31{ }^{\circ} \mathrm{C}$, respectively. The mean annual relative humidity is $95 \%$ in the morning and about $60 \%$ at noon. The soil at the experimental site is ferric Acrisol. 


\subsection{Experimental design}

A 2 x 5 factorial arrangement in randomized complete block design with three replications was used for the experiment. The factors were varieties at two levels: Agra Rice and Jasmine 85 and PGR at five levels: ATONIK at $450 \mathrm{ml} / \mathrm{ha}(32.4 \mu \mathrm{l} / 1$ of water per plant per application), ATONIK at 500 $\mathrm{ml} / \mathrm{ha}(36.0 \mu \mathrm{l} / \mathrm{l}$ of water per plant per application), ATONIK at $550 \mathrm{ml} / \mathrm{ha}(39.6 \mu \mathrm{l} / \mathrm{l}$ of water per plant per application), ATONIK at $0 \mathrm{ml} / \mathrm{ha}$ and $\mathrm{GA}_{3}$ at $60 \mathrm{ml} / \mathrm{ha}(4.32 \mu \mathrm{l} / 1$ of water/plant). The active ingredients of ATONIK are Sodium para-nitrophenolate, Sodium ortho-nitrophenolate and Sodium 5nitroguaiacolate. The experiment was set up in plastic basins where each basin represented a plot.

\subsection{Experimental procedure}

\section{Nursery management}

Seeds of the two varieties, were obtained from the CSIR-Crops Research Institute, Fumesua. The nursery was carried out in nursery trays in the plant house at the Department of Horticulture. Rice husk ash was used as the media. The seeds were sown on 6th July, 2015 at the rate of one seed per tray hole. The seeds were slightly covered with the rice husk and watered regularly. At 4 and 7 days after sowing, 98\% germination was achieved for Jasmine 85 and Agra Rice, respectively.

\section{Preparation of plastic basins for planting and transplanting}

Top soil dug from the Department was sieved to remove plant debris, plastic materials and broken glasses. The sieved soil was put in a metal container tray and sterilized for 30 minutes at $100^{\circ} \mathrm{C}$. The sterilized soil was then spread on a large tarpaulin, covered and left overnight to cool. Plastic basins each measuring $60 \mathrm{~cm}$ (diameter) $\mathrm{x} 70 \mathrm{~cm}$ (height) was filled with $21.3 \mathrm{~kg}$ of the cooled sterilized soil. Thorough watering was then done to allow the soil to settle prior to transplanting. On 14th July, 2015, the rice seedlings were transplanted into the soil and watered. At fortnightly interval, a hand fork was used to stir the soil to enhance soil aeration. On 3rd August, 2015, 21 days after transplanting, compound fertilizer (NPK 15-15-15) was applied to the seedlings at a rate of $1.2 \mathrm{~g}$ per plant. Watering was done judiciously in the mornings and late afternoons and weeds were handpicked every two weeks. The ATONIK treatments were applied on two occasions on 11th August, 2015 (30 days after transplanting) and on 10th September, 2015 (60 days after transplanting). The $\mathrm{GA}_{3}$ at $60 \mathrm{ml} / \mathrm{ha}$ was applied on 7th October, 2015, at heading of rice. Both ATONIK and $\mathrm{GA}_{3}$ were applied as foliar spray. Stem borers that attacked the rice plants were controlled using Farin (Chlorpyrifos) at a rate of $20 \mathrm{ml} \mathrm{l}^{-1}$ of water on 20th and 27th September, 2015. Rice blast attack was controlled using Goldazim (Cabendazim) at a rate of $10 \mathrm{ml} \mathrm{l}^{-1}$ of water on 11th, 18th and 25th September, 2015. Harvesting was done on 17th November for Jasmine 85 and 24th November for Agra Rice. Data were collected on the following parameters; (i) Plant height $(\mathrm{cm})$ - using a metre rule the height of the ten rice plants were measured from the base of the plant (at soil level) to the apex. The plant height was recorded two weeks after transplanting and was repeated for every two weeks (ii) Number of tillers - the number of tillers were counted every two weeks on the same ten plants (iii) Number of productive tillers - the number of tillers that produced panicles were counted and recorded as productive tillers (iv) Number of panicles - the number of panicles on the tillers were counted on the same ten plants (v) Grain weight (g) - the weight of harvested rice grains were obtained using an electronic balance (vi) Harvest index (\%) - this was calculated as (dry mass of harvested component / total shoot dry mass) x 100.

\subsection{Data Analysis}

Data collected were subjected to analysis of variance using Statistix version 9.0. The Least Significant Difference (LSD) was used for mean separation at a probability level set at $\mathrm{p}=0.05$. 


\section{Results}

\subsection{Effects of PGR on plant height of two rice varieties}

There were significant variety $\mathrm{x}$ plant growth regulator (PGR) interactions for plant height at 41 days after transplanting (DAT) (Tab. 1), 48 DAT (not shown), 62 DAT (not shown) and 76 DAT (not shown) and 90 DAT (Tab. 2). At 41 DAT, Agra Rice sprayed with ATONIK at $500 \mathrm{ml} /$ ha produced the tallest plants, significantly greater in height than all the Jasmine 85-PGR treatment combinations but similar to the other Agra Rice-PGR combinations. The shortest plants was produced by Jasmine 85 sprayed with ATONIK at $450 \mathrm{ml} / \mathrm{ha}$. Similar trends were observed until 90 DAT when the trend changed. At 90 DAT, Agra Rice sprayed with ATONIK at $450 \mathrm{ml} / \mathrm{ha}$ produced the tallest plants, significantly greater in height than all the Jasmine 85-PGR treatment combinations and the Agra Rice - NO PGR combination but similar to the other Agra Rice-PGR combinations. The shortest plants was also produced by Jasmine 85 sprayed with ATONIK at $450 \mathrm{ml} / \mathrm{ha}$. Generally, Agra Rice plants were significantly taller than Jasmine 85 plants over the period of the study.

Tab. 1 Effect of plant growth regulators on the plant height of two varieties of rice at 41 DAT.

\begin{tabular}{lccc}
\hline & Agra Rice $(\mathrm{cm})$ & Jasmine 85 $(\mathrm{cm})$ & Mean \\
\hline Atonik 450 & 79.70 & 70.73 & 75.22 \\
Atonik 500 & 84.20 & 75.33 & 79.77 \\
Atonik 550 & 81.27 & 72.93 & 77.10 \\
GA3 & 81.13 & 74.27 & 77.70 \\
No PGR & 79.53 & 74.33 & 76.93 \\
Mean & 81.17 & 73.52 & \\
\hline Lsd 5\% & PGR $=4.822 ;$ Variety $=3.050 ;$ PGR x Var $=6.820$ & \\
\hline
\end{tabular}

Tab. 2 Effect of plant growth regulators on the plant height of two varieties of rice at 90 DAT.

\begin{tabular}{lccc}
\hline & Agra Rice $(\mathrm{cm})$ & Jasmine 85 $(\mathrm{cm})$ & Mean \\
\hline Atonik 450 & 101.00 & 88.53 & 94.77 \\
Atonik 500 & 99.93 & 91.53 & 95.73 \\
Atonik 550 & 95.87 & 90.67 & 93.27 \\
GA3 & 95.8 & 88.67 & 92.23 \\
No PGR & 89.80 & 86.73 & 88.27 \\
Mean & 96.48 & 89.23 & \\
\hline Lsd 5\% & PGR $=5.754 ; \quad$ Var $=3.639 ;$ & PGR $x$ Var $=8.136$ & \\
\hline
\end{tabular}

\subsection{Effects of PGR on shoot and root fresh weight of two rice varieties}

There were significant variety $x$ PGR interactions for the shoot weight of rice at 90 DAT (Tab. 3). Jasmine 85 sprayed with $\mathrm{GA}_{3}$ at $60 \mathrm{ml} /$ ha produced the heaviest shoot weight, significantly greater than all the Agra Rice-PGR combinations as well as the Jasmine 85-ATONIK at 450ml/ha and Jasmine 85-No PGR combinations. The least shoot weight was produced by Jasmine 85 sprayed with ATONIK at $450 \mathrm{ml} / \mathrm{ha}$. Generally, application of $\mathrm{GA}_{3}$ at $60 \mathrm{ml} / \mathrm{ha}$ resulted in the highest shoot weight whereas application of ATONIK at $450 \mathrm{ml} / \mathrm{ha}$ resulted in significantly the least shoot weight.

There were also significant variety $\mathrm{x}$ PGR interactions for the root weight of rice at 90 DAT (Tab. 4). Both Agra Rice and Jasmine 85 sprayed with ATONIK at $450 \mathrm{ml} / \mathrm{ha}$ produced the heaviest root weight, significantly greater than the root weight of the other treatment combinations. The lowest root weight was produced by Agra Rice with no PGR application. Generally, application of ATONIK at $450 \mathrm{ml} / \mathrm{ha}$ resulted in the production of the greatest root mass whereas no PGR application resulted in the production of the lowest root mass. 
Tab. 3 Effect of plant growth regulators on the shoot fresh weight of two varieties of rice at 90 DAT.

\begin{tabular}{cccc}
\hline & Agra Rice $(\mathrm{g})$ & Jasmine 85 $(\mathrm{g})$ & Mean \\
\hline Atonik 450 & 266.0 & 343.20 & 304.6 \\
Atonik 500 & 281.73 & 382.33 & 332.03 \\
Atonik 550 & 288.57 & 377.07 & 332.82 \\
GA3 & 261.60 & 416.53 & 339.07 \\
No PGR & 269.73 & 362.53 & 316.13 \\
Mean & 273.53 & 376.33 & \\
\hline Lsd 5\% & PGR = 35.07; Var $=22.18 ; \quad$ PGR x Var $=49.60$ \\
\hline
\end{tabular}

Tab. 4 Effect of plant growth regulators on the root fresh weight of two varieties of rice at 90 DAT.

\begin{tabular}{cccc}
\hline & Agra Rice $(\mathrm{g})$ & Jasmine 85 $(\mathrm{g})$ & Mean \\
\hline Atonik 450 & 900 & 900 & 900 \\
Atonik 500 & 850 & 450 & 650 \\
Atonik 550 & 800 & 450 & 625 \\
GA3 & 393.3 & 650 & 520 \\
No PGR & 400 & 400 & 400 \\
Mean & 668.7 & 570 & \\
\hline Lsd 5\% & PGR $=22.15 ;$ & Var $=14.01 ;$ & PGR x Var $=31.32$ \\
\hline
\end{tabular}

\subsection{Effects of PGR on number of panicles of two rice varieties}

There were significant variety x PGR interactions for the number of heads at 90 DAT (Tab. 5). Agra Rice sprayed with ATONIK at $450 \mathrm{ml} /$ ha produced the highest number of heads, significantly greater than either Agra Rice or Jasmine 85 to which no PGR was applied but similar to all the other Agra Rice-PGR and Jasmine 85-PGR combinations. The least number of heads was produced by Jasmine 85 with no PGR application. Generally, application of ATONIK at $450 \mathrm{ml} / \mathrm{ha}$ and ATONIK at $500 \mathrm{ml} / \mathrm{ha}$ resulted in significantly higher number of panicles than the control (no PGR) but similar to that produced by application of $\mathrm{GA}_{3}$ at $60 \mathrm{ml} / \mathrm{ha}$.

Tab. 5 Effect of plant growth regulators on the number of panicles of two varieties of rice at 90 DAT.

\begin{tabular}{cccc}
\hline & Agra Rice & Jasmine 85 & Mean \\
\hline Atonik 450 & 37.33 & 36.33 & 36.83 \\
Atonik 500 & 34.33 & 34.0 & 34.17 \\
Atonik 550 & 32.67 & 31.33 & 32.0 \\
GA3 & 31.67 & 32.67 & 32.17 \\
No PGR & 29.33 & 25.0 & 27.17 \\
Mean & 33.07 & 31.87 & PGR x Var $=7.828$ \\
\hline Lsd 5\% & PGR = 5.535; Var = 3.501; & & \\
\hline
\end{tabular}

Comparing the ATONIK rates with the $\mathrm{GA}_{3}$, ATONIK at $450 \mathrm{ml} / \mathrm{ha}$ resulted in a $14.3 \%$ increase in the number of panicles produced by rice whiles ATONIK at $500 \mathrm{ml} / \mathrm{ha}$ recorded only a 6.2 $\%$ increase in the panicle numbers (Fig. 1). Interestingly, ATONIK at $550 \mathrm{ml} / 1$ resulted in a decrease in the number of panicles produced as compared with that of $\mathrm{GA}_{3}$.

However when all the PGRs were compared with no PGR application, ATONIK at 450 $\mathrm{ml} / \mathrm{ha}$ resulted in a $35.3 \%$ increase in the number of panicles whiles ATONIK at $500 \mathrm{ml} / \mathrm{ha}$ recorded a 25.7. \% increase in the panicle numbers (Fig. 2). ATONIK at $550 \mathrm{ml} / \mathrm{ha}$ and $\mathrm{GA}_{3}$ at $60 \mathrm{ml} / \mathrm{ha}$ also recorded increases of $17.6 \%$ and $18.4 \%$, respectively. 


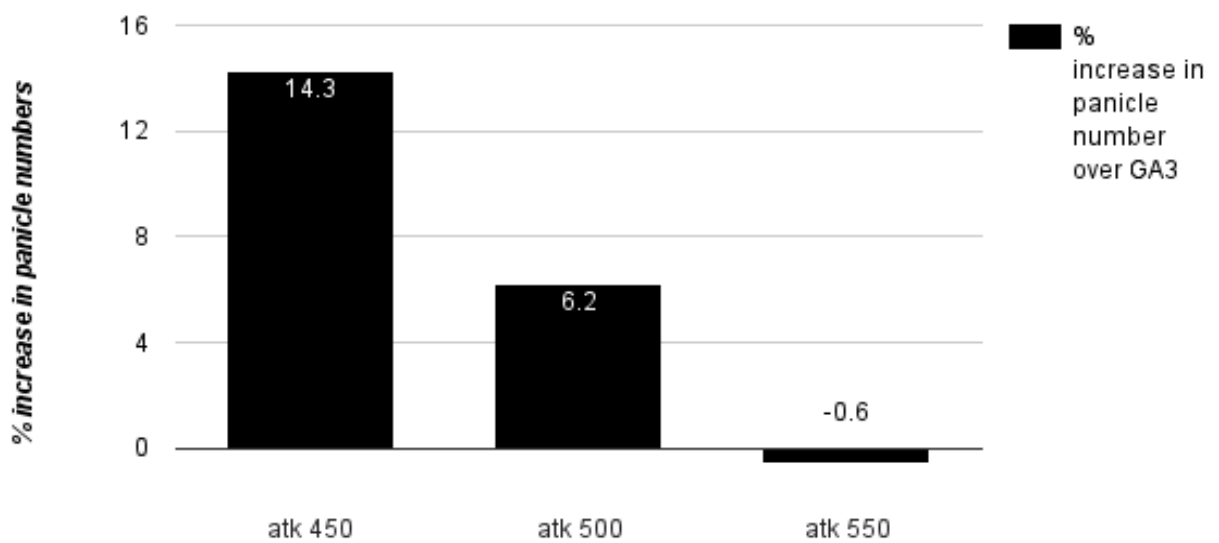

ATONIK plant growth regulator

Fig. 1 Percent increase in number of panicles at various ATONIK rates as compared with GA3 rate.
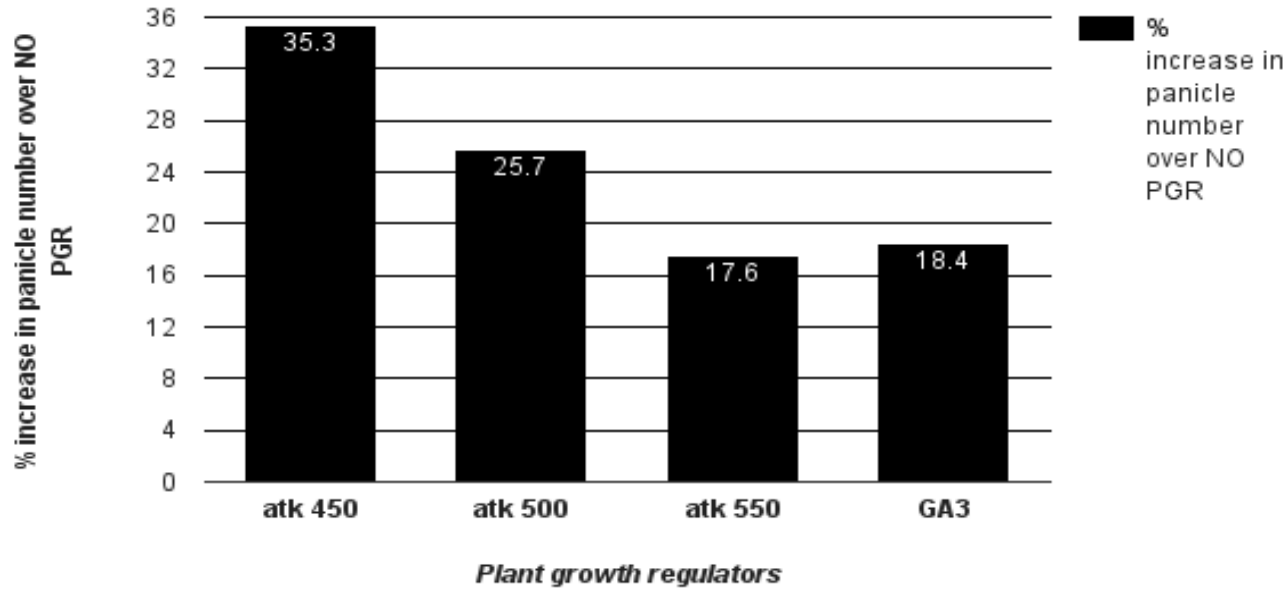

Fig. 2 Percent increase in number of panicles at various PGR rates as compared with NO PGR application.

\subsection{Effects of PGR on number of tillers of two rice varieties}

There were significant variety $x$ PGR interactions for the number of tillers at 27 DAT (Tab. 6), 41 DAT (not shown), 48 DAT (not shown), 62 DAT (not shown), 76 DAT (not shown) and 90 DAT (Tab. 7). At 27 DAT, Jasmine 85 sprayed with ATONIK at $450 \mathrm{ml} /$ ha produced the greatest number of tillers, significantly higher than all the Agra Rice - PGR treatment combinations but similar to the other Jasmine 85 - PGR combinations. The least number of tillers was produced by Agra Rice sprayed with $\mathrm{GA}_{3}$. Similar trends were observed until 90 DAT when the trend changed. At 90 DAT, Jasmine 85 sprayed with $\mathrm{GA}_{3}$ produced the highest number of tillers, significantly greater in number of tillers than all the Agra Rice-PGR treatment combinations, but similar to the other Jasmine 85 -PGR combinations. The least number of tillers was produced by Agra Rice sprayed with $\mathrm{GA}_{3}$.

Tab. 6 Effect of plant growth regulators on the number of tillers of two varieties of rice at 27 DAT.

\begin{tabular}{cccc}
\hline & Agra Rice & Jasmine 85 & Mean \\
\hline Atonik 450 & 24.38 & 37.8 & 31.09 \\
Atonik 500 & 26.73 & 34.3 & 30.53 \\
Atonik 550 & 23.47 & 32.93 & 28.2 \\
GA3 & 22.27 & 34.2 & 28.23 \\
No PGR & 23.47 & 34.3 & 28.9 \\
Mean & 24.06 & 34.72 & \\
\hline Lsd 5\% & PGR = 5.040; Var = 3.187; & PGR x Var = 7.127
\end{tabular}


Tab. 7 Effect of plant growth regulators on the number of tillers of two varieties of rice at 90 DAT.

\begin{tabular}{cccc}
\hline & Agra Rice & Jasmine 85 & Mean \\
\hline Atonik 450 & 54.87 & 68.33 & 61.6 \\
Atonik 500 & 57.93 & 60.4 & 59.17 \\
Atonik 550 & 52.4 & 65.0 & 58.7 \\
GA3 & 51.73 & 71.67 & 61.7 \\
No PGR & 44.87 & 62.77 & 53.82 \\
Mean & 52.36 & 65.63 & \\
\hline Lsd 5\% & PGR $=9.058 ;$ & Var $=5.729 ;$ & PGR x Var $=12.809$ \\
\hline
\end{tabular}

Among the PGR treatments, application of ATONIK at $450 \mathrm{ml} / \mathrm{ha}$ resulted in the highest percentage of productive tillers followed by ATONIK at $500 \mathrm{ml} / \mathrm{ha}$, ATONIK at $550 \mathrm{ml} / \mathrm{ha}$ and $\mathrm{GA}_{3}$ at $60 \mathrm{ml} / \mathrm{ha}$ (Fig. 3). In comparing the PGR applications with No PGR, the least percentage of productive tillers was produced by the rice where No PGR application was made (Fig. 3). Application of ATONIK at $450 \mathrm{ml} / \mathrm{h}$ a resulted in a $14.4 \%$ higher percentage of productive tillers than that produced by $\mathrm{GA}_{3}$ at $60 \mathrm{ml} / \mathrm{ha}$. Similarly, ATONIK at $500 \mathrm{ml} / \mathrm{ha}$ and ATONIK at $550 \mathrm{ml} / \mathrm{ha}$ also resulted in $10.7 \%$ and 4.4 $\%$ higher percentage of productive tillers than that of $\mathrm{GA}_{3}$ at $60 \mathrm{ml} / \mathrm{ha}$ (Fig. 4). However, when the PGR rates were compared with the no PGR application, the extent of increase in the productive tillers was higher such that application of ATONIK at $450 \mathrm{ml} / \mathrm{ha}$ resulted in an $18 \%$ higher percentage of productive tillers than that produced without any PGR application (Fig. 5). Similarly, application of ATONIK at $500 \mathrm{ml} / \mathrm{ha}$, ATONIK at $550 \mathrm{ml} / \mathrm{ha}$ and $\mathrm{GA}_{3}$ at $60 \mathrm{ml} / \mathrm{ha}$ resulted in $14.2 \%, 7.7 \%$, and 3.2 $\%$, respectively more productive tillers that that without PGR application.

\subsection{Effects of PGR on grain yield and harvest index of two rice varieties}

Grain yield of rice was highest under ATONIK at $450 \mathrm{ml} / \mathrm{ha}$ application, significantly greater than those under $\mathrm{GA}_{3}$ at $60 \mathrm{ml} / \mathrm{ha}$ and no PGR (Fig. 6). The least grain yield was produced by rice to which no PGR was applied. When the ATONIK rates were compared with $\mathrm{GA}_{3}$ at $60 \mathrm{ml} / \mathrm{ha}$, ATONIK at $450 \mathrm{ml} / \mathrm{ha}$ application led to a $17.8 \%$ increase in grain yield whiles ATONIK at $500 \mathrm{ml} / \mathrm{ha}$ and ATONIK at $550 \mathrm{ml} /$ ha led to $14.9 \%$ and $9.2 \%$, respectively (Fig. 7). However, in comparison to no PGR application, ATONIK at $450 \mathrm{ml} / \mathrm{ha}$ application led to a $33.9 \%$ increase in grain yield whiles ATONIK at $500 \mathrm{ml} / \mathrm{ha}$, ATONIK at $550 \mathrm{ml} / \mathrm{ha}$ and $\mathrm{GA}_{3}$ at $60 \mathrm{ml} / \mathrm{ha}$ led to increases of $30.6 \%, 24.1 \%$ and $13.7 \%$, respectively (Fig. 8).

As regards the harvest index, application of ATONIK at $450 \mathrm{ml} / \mathrm{ha}$ resulted in the highest harvest index of $45 \%$ which was significantly greater than the other PGR treatments (Fig. 9). In descending order, the harvest indices for the other PGR rates were $40 \%$ (ATONIK at $500 \mathrm{ml} / \mathrm{ha}$ ), 38 $\%$ (ATONIK at $550 \mathrm{ml} / \mathrm{ha}$ ), $35 \%\left(\mathrm{GA}_{3}\right.$ at $60 \mathrm{ml} / \mathrm{ha}$ ) and $33 \%$ (no PGR) (Fig. 9). When the ATONIK rates were compared with the $\mathrm{GA}_{3}$ rate, application of ATONIK at $450 \mathrm{ml} / \mathrm{ha}$ led to a $28.6 \%$ increase in harvest index whereas ATONIK at $500 \mathrm{ml} / \mathrm{ha}$ and ATONIK at $550 \mathrm{ml} / \mathrm{ha}$ led to increases of $14.3 \%$ and $8.6 \%$, respectively (Fig. 10). In comparison to no PGR application, application of ATONIK at 450 $\mathrm{ml} / \mathrm{ha}$ led to a $36.4 \%$ increase in harvest index whereas ATONIK at $500 \mathrm{ml} / \mathrm{ha}$, ATONIK at $550 \mathrm{ml} / \mathrm{ha}$ and $\mathrm{GA}_{3}$ at $60 \mathrm{ml} / \mathrm{ha}$ led to increases of $21.2 \%, 15.2 \%$ and 6.1\%, respectively (Fig. 11). 
Banful and Attivor

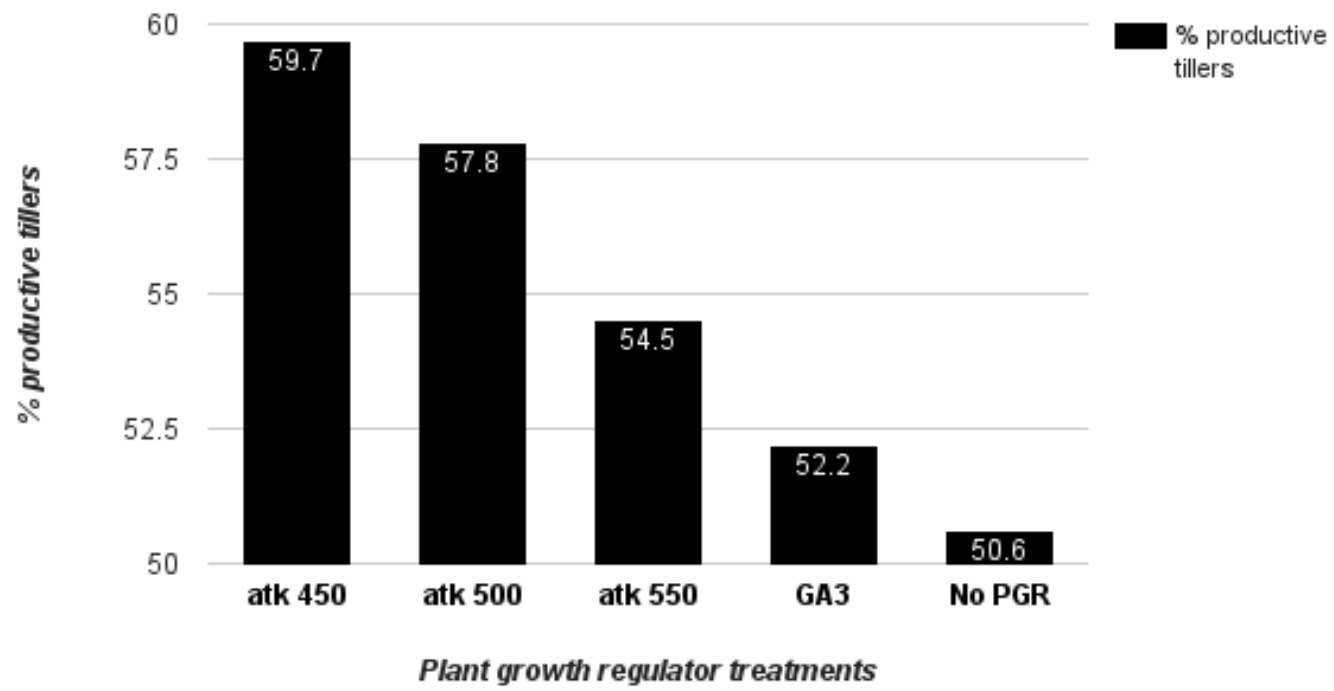

Fig. 3 Percent productive tillers under various PGRs.

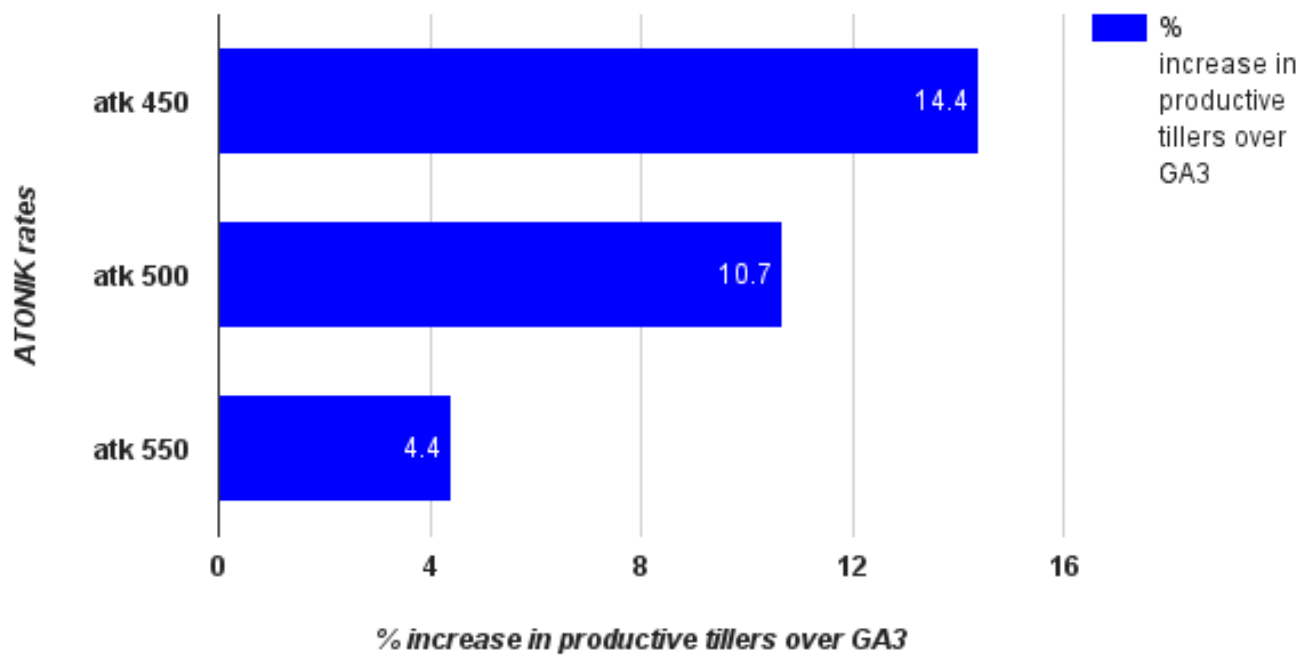

Fig. 4 Percent increase in productive tillers under various ATONIK rates in comparison with GA3.

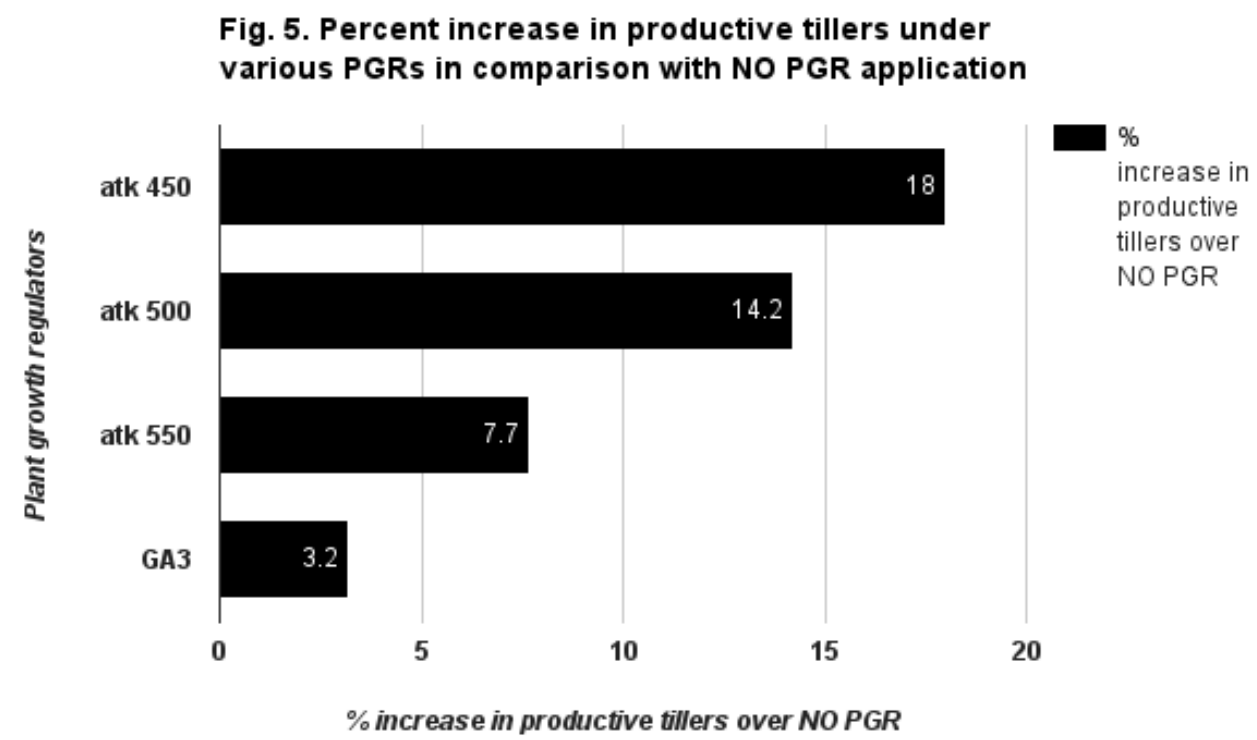

Fig. 5 Percent increase in productive tillers under various PGRs in comparison with NO PGR application. 


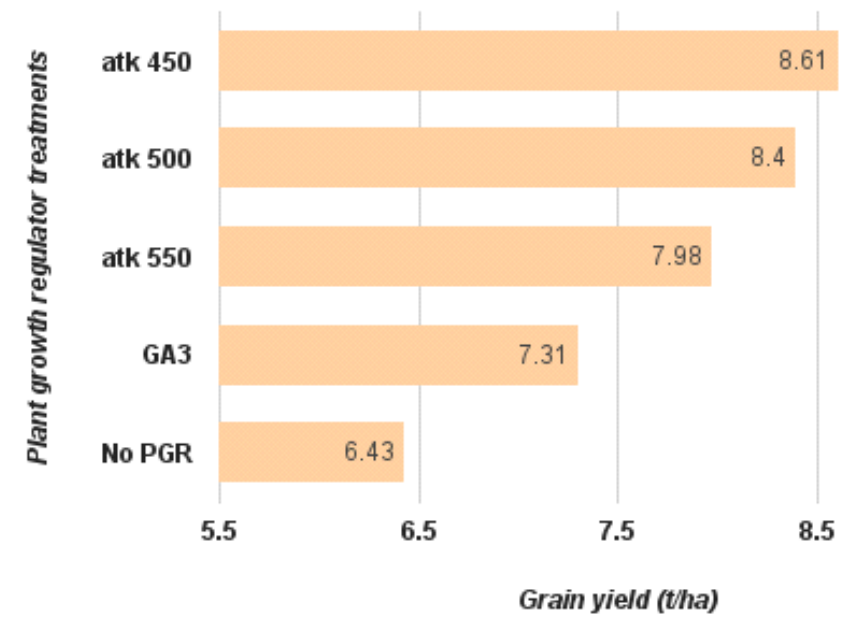

Grain yield

Grain
(t/ha)

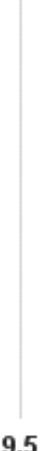

9.5

Fig. 6 Grain yield under various PGRs and the control (No PGR).

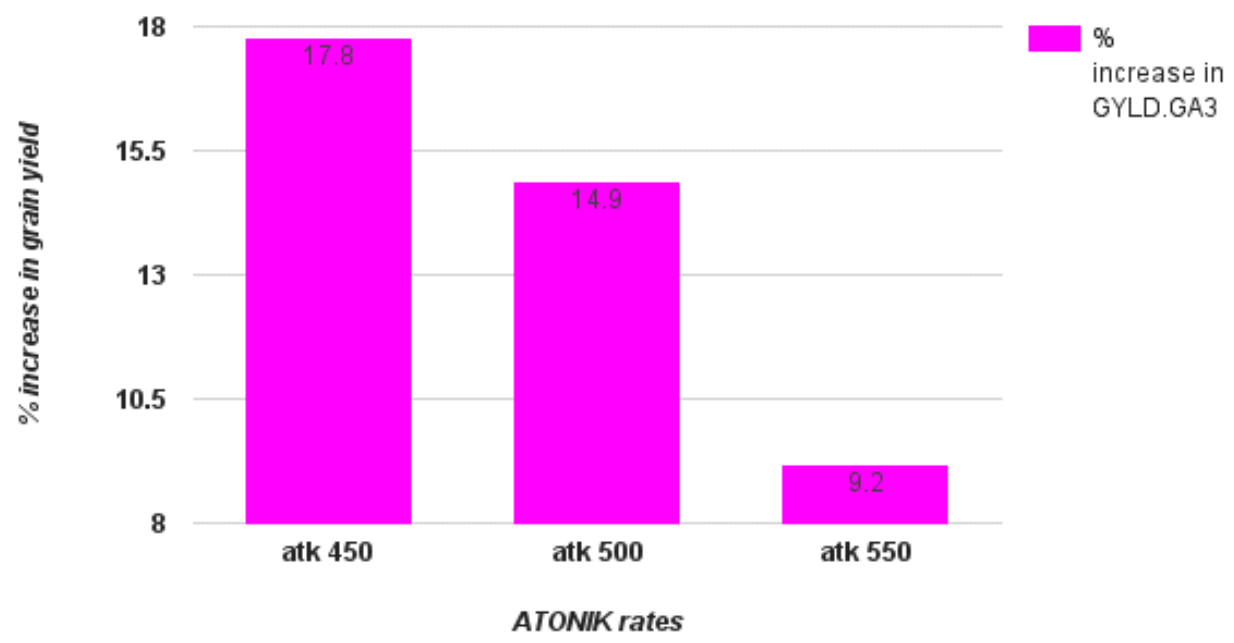

Fig. 7 Percent increase in grain yield under various ATONIK rates in comparison with GA3 rate.

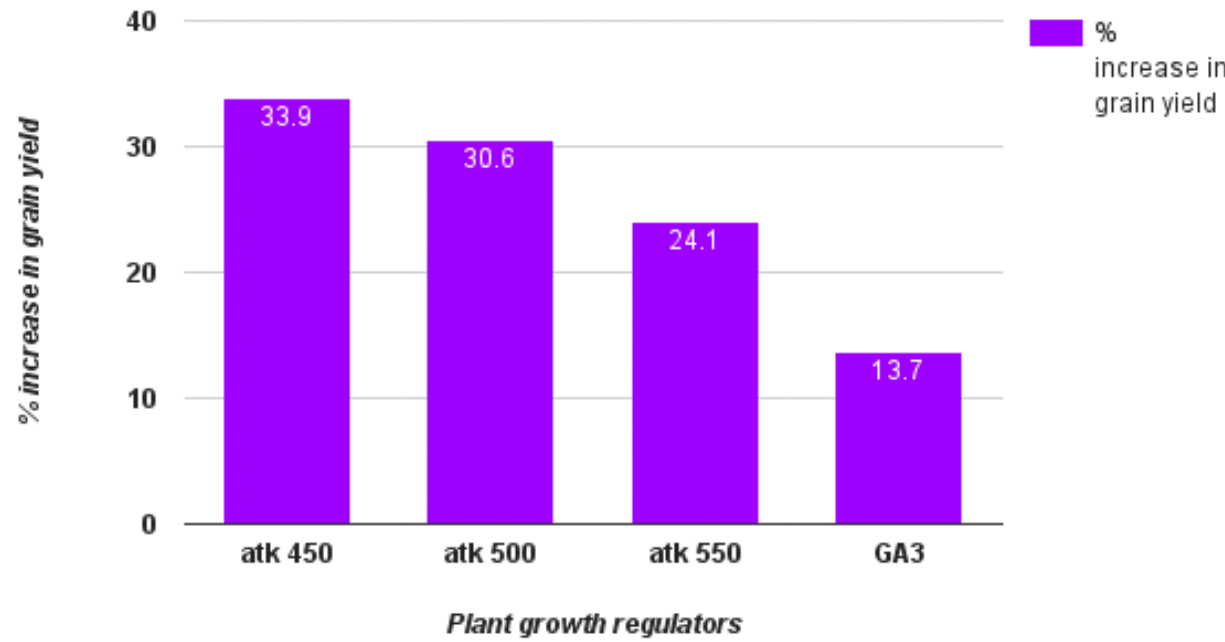

Fig. 8 Percent increase in grain yield under various PGRs in comparison with NO PGR. 
50.0

อั
45.0

4

40.0

45.0

35.0

30.0

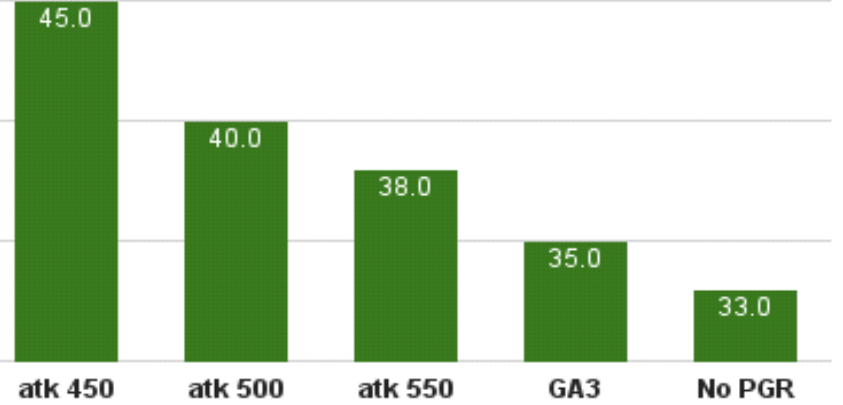

Plant growth regulator treatments

Fig. 9 Harvest index of rice under various PGRs.

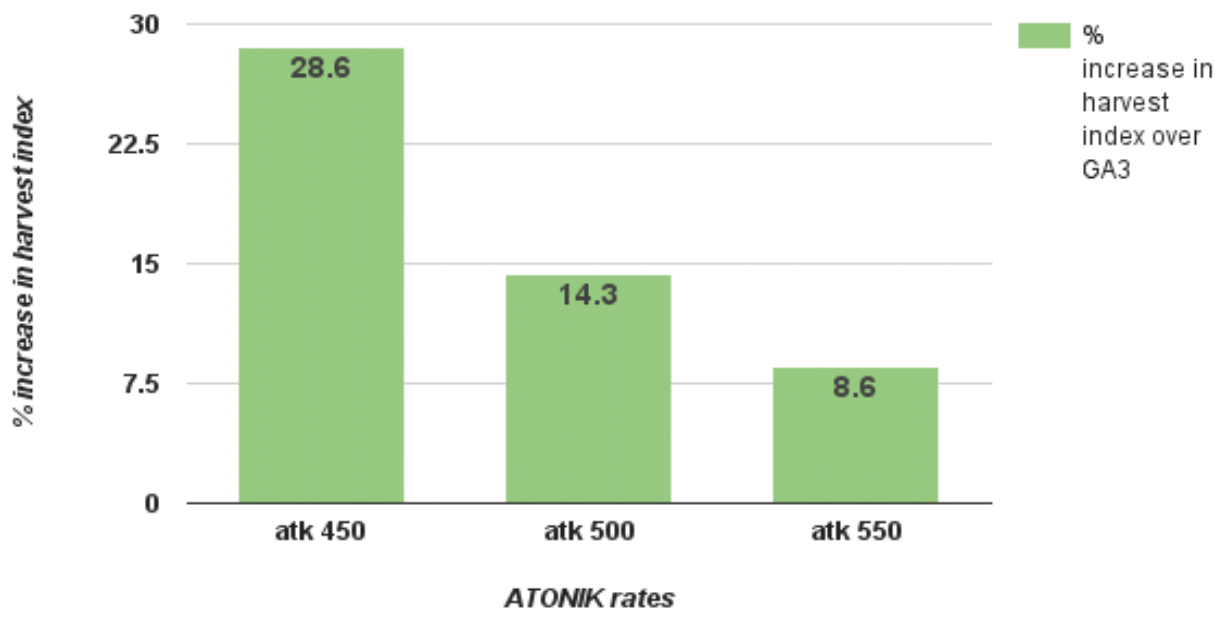

Fig. 10 Percent increase in harvest index of ATONIK rates in comparison with GA3 rate.

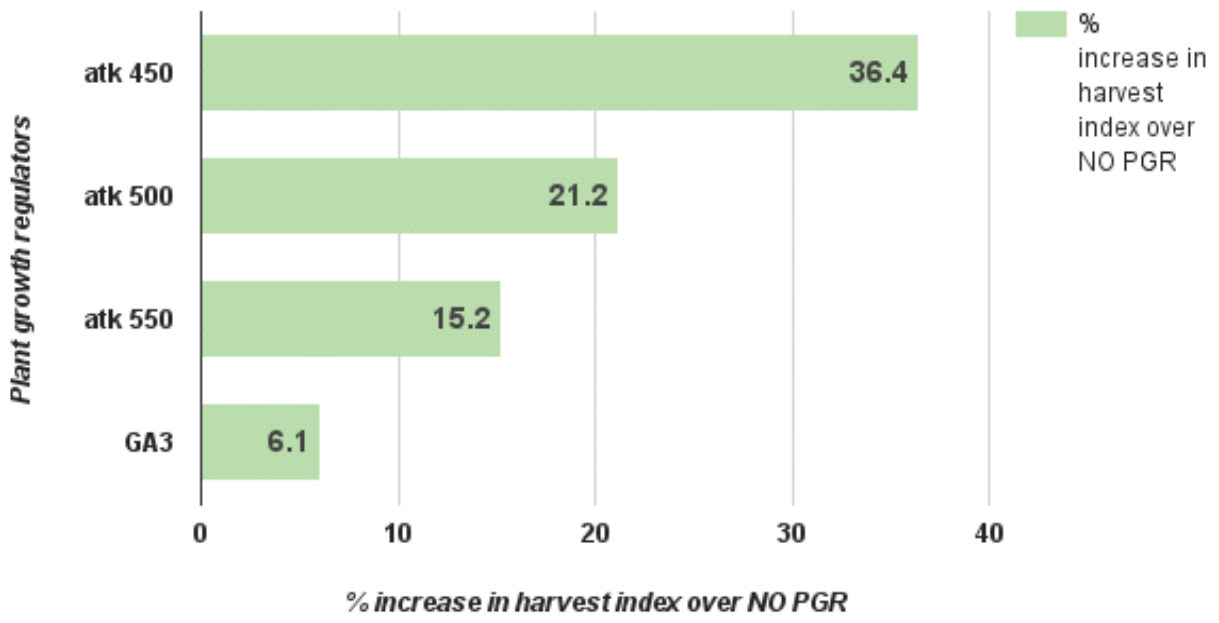

Fig. 11 Percent increase in harvest index of PGRs in comparison with NO PGR.

\section{Discussion}

Plant growth regulators play important roles in plant growth, development, yield and qualities formation (Ekamber and Kumar 2007; Rajendra and Jones Jonathan 2009). Solaimalai et al. (2001) found that suitable application of plant growth regulators could improve the photosynthetic capacity and promote the rate of rice seed-setting. In the present study, ATONIK PGR was comparable to GA 3 
in increasing plant height over the study period. These findings were in close agreement with the results of Subbaih and Mittra (1997) and Dunand (1998) who also reported of significant increases in plant height and stem elongation in rice when plant growth regulators were applied. The increase in plant height could be the result of an enhanced vegetative growth emanating from active cells division, cells enlargement and cells elongation (Pareek et al. 2000). In addition, application of ATONIK at $450 \mathrm{ml} / \mathrm{ha}$ resulted in the production of the greatest root mass whereas no PGR application resulted in the production of the lowest root mass. Peng et al. (1999) reported that application of PGR increased root biomass and root activity. All the ATONIK rates and $\mathrm{GA}_{3}$ rate, resulted in significant increases in the number of panicles, the greatest of $35.5 \%$ being produced from the application of ATONIK at 450 $\mathrm{ml} / \mathrm{ha}$. Among the PGR treatments, application of ATONIK at $450 \mathrm{ml} / \mathrm{ha}$ resulted in the highest percentage of productive tillers followed by ATONIK at $500 \mathrm{ml} / \mathrm{ha}$, ATONIK at $550 \mathrm{ml} / \mathrm{ha}$ and $\mathrm{GA}_{3}$ at $60 \mathrm{ml} / \mathrm{ha}$. Rice plants to which no PGR was applied produced the least percentage of productive tillers. Application of ATONIK at $450 \mathrm{ml} / \mathrm{ha}$ resulted in a $14.4 \%$ higher percentage of productive tillers than that produced by GA3 at $60 \mathrm{ml} / \mathrm{ha}$. Similarly, ATONIK $500 \mathrm{ml} / \mathrm{ha}$ and ATONIK $550 \mathrm{ml} / \mathrm{ha}$ also resulted in $10.7 \%$ and $4.4 \%$ higher percentage of productive tillers than that of $\mathrm{GA}_{3}$ at $60 \mathrm{ml} / \mathrm{ha}$. More effective tillers per plant are believed to be closely associated with high seed yield per plant resulting in high productivity. Hybrid rice relies mainly on tillers to obtain desirable population and about $85-90 \%$ of productive panicles of hybrid rice come from tillers (Elankavi et al. 2009). All the PGR rates resulted in increases in grain yield in comparison to no PGR application. In this regard, ATONIK at $450 \mathrm{ml} / \mathrm{ha}$ application led to a $33.9 \%$ increase in grain yield whiles ATONIK at $500 \mathrm{ml} / \mathrm{ha}$, ATONIK at $550 \mathrm{ml} / \mathrm{ha}$ and $\mathrm{GA}_{3}$ at $60 \mathrm{ml} / \mathrm{ha}$, led to increases of $30.6 \%, 24.1 \%$ and $13.7 \%$, respectively. Following a similar trend, Elankavi et al. (2009) reported a 13\% higher seed yield with application of GA3 at $60 \mathrm{ml} / \mathrm{ha}$ in rice. Furthermore, Elankavi et al. (2009) also reported an up to $50.5 \%$ increase in grain yields over no PGR application. Biological yield significantly increases with the application of PGR and larger panicle is associated with high number of grain panicles which culminate in high productivity (Kalavathi et al. 2000; Shi-Hua 2006). Thus when the ATONIK rates were compared with $\mathrm{GA}_{3}$ at $60 \mathrm{ml} / \mathrm{ha}$, ATONIK at $450 \mathrm{ml} / \mathrm{ha}$ application led to a $17.8 \%$ increase in grain yield whiles ATONIK at $500 \mathrm{ml} / \mathrm{ha}$ and ATONIK at $550 \mathrm{ml} / \mathrm{ha}$ led to $14.9 \%$ and $9.2 \%$, respectively. Such increases in grain yield might be due to the fact that the ATONIK PGR enhanced the promotion of a more effective translocation of photosynthates produced from an increased mobilization of reserve food materials to the developing sink through an increase in the hydrolyzing and oxidizing activities of enzymes (Jayachandran et al. 2000). Application of PGR also enhances lodging resistance and increases the root activity of rice to improve phosphorus and potassium accumulation in the rice stem, leaves and grains (Peng et al. 1999). In the present study, such enhanced root activity was obtained from the application of the ATONIK which led to harvest index increases of $28.6 \%$ for ATONIK at $450 \mathrm{ml} / \mathrm{ha}, 14.3 \%$ for ATONIK at 500 $\mathrm{ml} / \mathrm{ha}$ and $8.6 \%$ for ATONIK at $550 \mathrm{ml} / \mathrm{ha}$ comparative to $\mathrm{GA}_{3}$ at $60 \mathrm{ml} / \mathrm{ha}$.

\section{Conclusion}

The study clearly demonstrated that ATONIK PGR was superior to $\mathrm{GA}_{3}$ in the vegetative and productive performance of rice. Consequently, ATONIK application resulted in the tallest plants with the highest number of panicles and productive tillers. In addition, ATONIK application produced an increased root mass which better exploited the soil environment and subsequently culminated in the production of high rice yields with an enhanced efficiency of dry matter partitioning which led to a high harvest indices. The study concludes that application of PGRs are good for increased rice productivity, the best being ATONIK at a rate of $450 \mathrm{ml} / \mathrm{ha}$. 


\section{References}

Abel S, Theologis A (2010) Odyssey of Auxin. In: Perspectives in Biology. Estelle M, Weijers D, Ljung K, Leysers O (Eds). Cold Spring Harbour Laboratory Press, USA.

Al-Hassan RM, Agbekornu HG, Sarpong, DB (2008) Consumer preference for rice quality characteristics in Accra and the effects of these preferences on price. Agricultural and Food Science Journal of Ghana 7:575-591.

Arysta LifeScience Limited (2014) ATONIK product information (online). www.arysta.hu

Bam RK, Anchirinah VM, Manful JT, Ansereh- Bio F, Agyemang A (1998) Improving the competitiveness and marketability of locally produced rice in Ghana: A preliminary study of consumer preferences and price/ quality relationships. DFID Crop Post Harvest Programme Project No.R6688 project Report. Pp. 65.

Dunand RT (1998) Effects of pre-heading application of gibberellic acid on rice growth and production. Proceedings of the $27^{\text {th }}$ Rice Technical Working group (RTGWG), 1998, Reno, NV, 211-211.

Ekamber K, Kumar MP (2007) Hormonal regulation of tiller dynamics in differentially-tillering rice cultivars. Plant Growth Regulators. 53:215-223.

Elankavi S, Kuppuswamy G, Vaiyapuri V, Raman R (2009) Effect of phytohormones on growth and yield of rice. Oryza, 46:310-313.

Emongor V (2007) Gibberellic acid influence on vegetative growth, nodulation and yield of cowpea. Journal of Agronomy, 6:509-517.

Food and Agriculture Organization (2008) Rice: production up by 1.8\%, according to forecasts: The market is still narrow and weak trade http://www.fao.org/ NEWSROOM/fr/news/2008/1000820/index.html Accessed: 14/04/14.

Gianfagna TJ (1987) Natural and synthetic growth regulators and their use in horticultural and agronomic crops, p:614-635. In Davis PJ (Ed). Plant hormones and their role in plant growth and develeopment. Martinus Nijhoff Publishers, Dordecht, Boston, Lancaster.

Jayachandran M, Gopel NO, Marimuthu R (2000) Performance of hybrid rice cultivars under different levels of nitrogen in combination with growth regulators. Madras Agricultural Journal, 89:462-465.

Kalavathi O, Ananthakalaiselvi A, Vijaya, J (2000) Economization of $\mathrm{GA}_{3}$ use in hybrid rice seed production by supplementing with other nutrients. Seed Research, 28:10-12.

Millennium Development Authority (2010) Investment Opportunity in Ghana: Maize, Rice and Soyabean. Accra, Ghana. 120 pp.

Ministry of Food and Agriculture (1999) Task force report on proposals for improving rice production and quality in Ghana, Ministry of Food and Agriculture, Accra, Ghana. 67pp.

Ministry of Food and Agriculture (2000) Report of the Committee on improving the quality of locally produced rice to reduce imports. Ministry of Food and Agriculture, Accra, Ghana. 85pp.

Ministry of Food and Agriculture (2011a) Agriculture in Ghana facts and figures (2010). Accra, Ghana: Statistics Research and Information Directorate MoFA. 53pp.

Nwanze KF, Mohapatra S, Kormawa P, Keya S, Bruce-Oliver S (2006) Rice development in subSaharan Africa. Journal of Science Food and Agriculture, 86:675-677.

Osei-Asare Y (2010) Mapping of Poverty Reduction Strategies and policies related to Rice Development in Ghana. Nairobi, Kenya: Coalition for African Rice Development (CARD).

Pareek NK, Jat NL, Pareek RG (2000) Response of coriander (Cirriandum sativum) to nitrogen and plant growth regulators, Haryana, Journal of Agronomy, 16:104-109.

Peng J, Richards DE, Hartley NM, Murphy GP, Devos KM (1999) Green revolution gene encodes mutant gibberellin response modulators. Nature, 400:256-261.

Rajendra B, Jones Jonathan DG (2009) Role of plant hormones in plant defense responses. Plant Molecular Biology, 69:473-488.

Richards DE, King KE, Ali AT, Harberd NP (2001) How gibberellin regulates plant growth and development: A molecular genetic analysis of gibberellin signaling. Annual Review of Plant Physiology and Plant Molecular Biology, 52:67-88.

Sakamoto T, Miura K, Tatsumi T, Ueguchitanaka M, Ishiyama K (2004) An overview of gibberellin metabolism enzyme and their related mutants in rice. Plant Physiology, 134:1642-1653. 
Banful and Attivor

Shah SH, Ahmad I, Samiullah (2006) Effect of gibberellic acid spray on growth, nutrient uptake and yield attributes at various growth stages of black cumin (Nigella sativa L.). Asian Journal of Plant Science, 5:881-884.

Shi-Hua V, Ben-Yi C, Jian-Li W, Wei-Feng S, Shi-Hua C (2006) Review and prospects in rice breeding and extension in China. Rice Science, 13:1-8.

Solaimalai A, Sivakumar C, Anbumani S, Suresh T, Arumugam K (2001) Role of plant growth regulators in rice production. A review. Agricultural Review, 22:33-40.

Subbaih G, Mittra BN (1997) Effect of foliar spray of micronutrient in growth and yield of rice. Oryza, 26:148-151.

Sun T (2004) Gibberellin signal transduction in stem elongation and leaf growth. In: Plant Hormones: biosynthesis, signal transduction and action. Davies PJ (Ed). Kluwer Academic Publishers, Dordrecht, The Netherlands. pp:304-320.

Woodward AW, Bartel B (2005) Auxin: regulation, action and interaction. Annals of Botany, 95:707735.

Xu S and Li B (1988) Managing hybrid rice seed production. Proceedings of the $1^{\text {st }}$ International Symposium on Hybrid Rice. Oct, 6-10, International Rice Research Institute, Manila, Philippines. 157-163. 